\title{
Mast Cells: The Key to Multiple Sclerosis?
}

\author{
Per Gøran Krüger \\ Institute of Biomedicine, University of Bergen, Bergen, Norway \\ Email: per.kruger@biomed.uib.no
}

Received 22 January 2014; revised 22 February 2014; accepted 1 March 2014

Copyright (C) 2014 by author and Scientific Research Publishing Inc.

This work is licensed under the Creative Commons Attribution International License (CC BY).

http://creativecommons.org/licenses/by/4.0/

(c) (i) Open Access

\begin{abstract}
Mast cells are present in high numbers in the border-zones of the multiple sclerosis-plaques. They are located in small clusters along capillaries and venules, and they are more abundant in females than in men. Mast cells can be stimulated to release specific mediators such as histamine, resulting in oedema formation, as well as proteases that may cause demyelination, by several different activation mechanisms. We hypothesize that a putative mast cell activation may be induced by diet factor(s) as well as long lasting mental stress that may lead to the release of catestatin, as well as ACTH released from the pituitary gland. Given a natural flux of mast cell recovery and activation, a putative phenomenon of massive release of mediators and "silent" reload periods may explain the relapsing-remitting phases of multiple sclerosis.
\end{abstract}

\section{Keywords}

Multiple Sclerosis, Mast Cells, Histamine, Mast Cell Proteases, Socio-Cultural Factors, Metabolic Factors, Mental Stress, Catestatin, Phtalates, Female, Male, Relapsing-Remitting

\section{Introduction}

Multiple sclerosis (MS) is an inflammatory demyelinating disease of the central nervous system (CNS). Numerous hypotheses related to the cause of MS have been suggested over the years. As yet, no published hypothesis explains all the satisfactory elements related to disease progression. It has been suggested that allergic factors contribute to the origin of MS lesions [1] and magnetic resonance imaging (MRI) has revealed a dynamic process locally in the white matter caused by repeated blood-brain barrier damage with subsequent oedema [2]. In Norway, the incidence of MS is lower in the far north compared to the south west [3] [4] and it is also lower in coastal fishing communities compared to agricultural areas [5]. A positive correlation between animal fat, milk and oat intake and risk of MS [6]-[14], supports the notion of a relationship between MS and diet intake. It has also been suggested that MS may be a rare sequel to a childhood infection, more precisely, at or shortly after puberty [15], which only becomes manifested after a long latency period [16]-[21]. Most of these reports are re- 
lated to measles. Death from MS does not appear to be more common than expected among nurses and doctors than in the general population [22] which indicates that MS in itself is not infectious.

\section{Mast Cells}

Mast cells were initially observed as granular cells in the mesenterium of the frog, and were named plasma cells by Waldeyer [23]. Ehrlich [24] discovered that these plasma cells contained metachromatically stainable granules and named them "Mastzellen”, “over nourished cells” (Mästung). The mast cells and blood basophils both have their origin in the bone marrow, but represent two separate lines of development [25]. The mast cell may display phagocytic function [26], and induce MHC Class II expression [27] that has led to the question: are the mast cells of monocytic origin? The mast cells express two different (some recognize three) phenotypes: connective tissue mast cells ("thymic independent") with the granular proteases chymase and tryptase, and mucosal mast cells ("thymic dependent") [28] with tryptase as the granule protease. In addition to the proteases, the secretory granules contain several other preformed secretory products among which are histamine and heparin. All these mediators may be released at various degrees and time-sequences from stimulated mast cells. Other mediators may be produced and released by activation of specific receptors such as leukotrienes and cytokines. Connective tissue mast cells may produce significant levels of interleukin-1 which facilitates lymphocyte infiltration [29] (an important observation seen in MS).The different mast cell phenotypes may react differently upon stimulation. For instance, Neurotensin may stimulate mast cells from rat pleural areas, but not mast cells from the peritoneal cavity [30]. Connective tissue mast cells may be stimulated by substance-P and morfine whereas mast cells from the heart may not be stimulated by substance-P [31] [32]. This indicates that the various mast cell phenotypes can have various biological and pathological functions in different tissues. Generally, after stimulation and mediator release, the mast cells survive and the secretory granules are restored [33].

\section{Mast Cells and MS}

In the normal and unaffected human brain mast cells are present only in area postrema, infundibulum and the pineal organ (and their surrounding leptomeninges) as well as in the choroid plexus, but not elsewhere in the brain and spinal chord [34]. In MS mast cells were originally observed by Neumann in 1890 [35] and confirmed by others to be in close contact to MS-plaques [36]-[40]. Yet many scientists focusing on MS conclude that the numbers are too low to be of any significance in relation to MS. However; reconstruction of some venules positioned in close vicinity to the MS-plaques (Figure 1: reconstruction and examples of mast cell locations) reveals that the mast cells are organized is small clusters along blood vessels [41] and that their numbers are approximately 10 times higher than earlier estimated. In addition, the numbers of mast cells in the border zones (defined

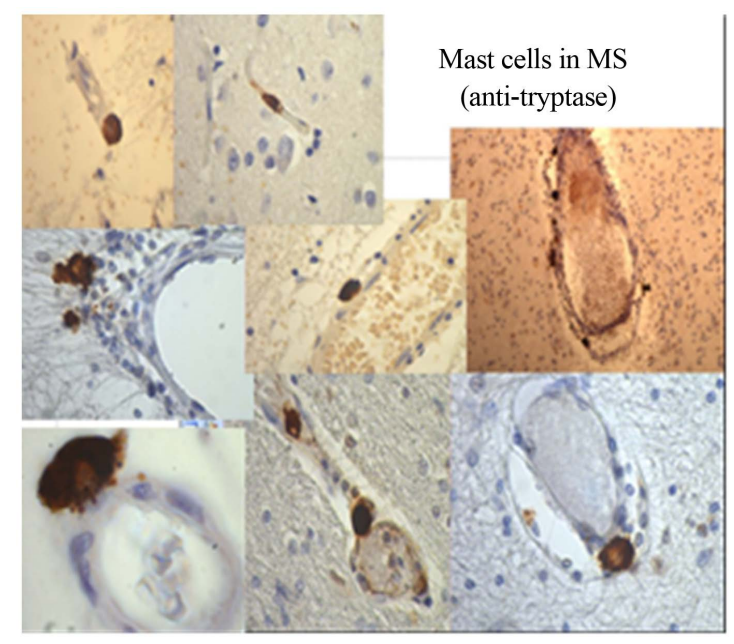

(a)
The mast cells in MS-plsques are mostly aggregated in small clusters along venules (Krüger 2001)
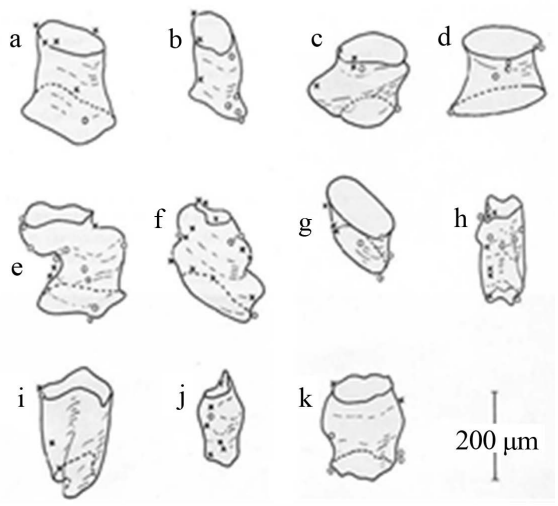

(b)

Figure 1. In Multiple sclerosis, mast cells are located at capillaries and venules in the border zones of the plaques: (a) and they are mostly aggregated in small clusters; (b) (reconstruction of venules in the borderzones of MS-plaques, depicting the actual position of individual mast cells). 
as a zone $1 \mathrm{~mm}$ around the actual plaque) of females is twice as high as in males [42], ( $\mathrm{p}<0.005)$. This observation is of interest based on the fact that females are more susceptible to developing MS compared to males [43].

A strong association between mast cells and MS is further strengthened by the fact that elevated mast cell tryptase is observed in the cerebrospinal fluid of MS patients [44]. Moreover, it is known that mast cell tryptase may dissolve the proteins of the myelin sheaths [45].

\section{Activation of Mast Cells, as Possible Cause(s) of MS}

The most well-known activation of mast cells is by specific antigens triggering sensitized mast cells. Some decades ago MS was low in coastal areas of Norway [46], and, as discussed elsewhere [47], the recent change in nutritional habits may explain why MS is now just as common in coastal as in inland communities. Thus; some unknown metabolic factors from nutrition may represent potent candidates as stimulators of the perivascular mast cells in the brains of MS-patients. However; other biological and socio-cultural factors may also play a role. For instance, ACTH [48] as well as Catestatin (a domaine within chromogranin-A-a secretory protein which is co-stored and co-released with neurotransmitters and peptide hormones in the diffuse neuroendocrine system) [49] are potent stimulators of mast cells. These factors may be released by mental stress leading to mast cell stimulation [50]. In summary, mast cells are located along venules in border-zones of MS-plaques, and more mast cells are observed around plaques in females compared to men. Mast cells do also release histamine and protease(s) upon stimulation. Histamine opens up venules that may lead to oedema, and mast cell proteases can dissolves myelin sheaths leading to demyelination. Mast cells may recover after depletion of their granule contents which may explain the relapsing remitting periods that characterize the disease.

\section{Suggestions}

The remarkable shift in incidence of MS in Norway being more common in inland than at the coast, and now also becoming a coastal phenomenon as well, indicates that the mast cell stimulating factor (s) have socio-cultural component. Probably a shift in nutritional habits, and even effects from these habits transferred epigenetically over generations may play a role. Other factors, however, cannot be excluded. Long lasting mental stress may play a role. Also phthalates emanating from common plastic wrappings introduced during the last 50 - 70 years may play a role. For instance, phthalates may have different, though often overlapping health effects [51], yet they have been shown to potentiate antibody-induced release from mast cells [52]. The common nature of MS: relapsing-remitting phases, may be explained by the release of histamine and proteases after a massive stimulation of the brain mast cells that can lead to oedema formation and demyelination characterised by the relapsing phase. In contrast the remitting phase occurs when the mast cells reload the stores of histamine and protease(s) which takes several weeks. A validity test for the influence of mast cells in MS would be applied in mast cells blockers in addition to antihistamins (that passes blood-brain-barrier): do the frequences of oedemas decrease?

\section{Acknowledgements}

I am deeply indebted to Professor Rolf Bjerkvig for his never-ending mental support and for his comments on my manuscript.

\section{References}

[1] Broman, T. (1947) Supravital Analysis of Disorders in the Cerebral Vascular Permeability. Two Cases of Multiple Sclerosis. Acta Psychiatrica et Neurologica Scandinavica, Supplementum, 45, 58-71.

[2] Kermode, A.G., Tofts, P.S., Thompson, A.J., et al. (1990) Heterogeneity of Blood-Brain Barrier Changes in Multiple Sclerosis: An MRI Study. Neurology, 40, 229-235. http://dx.doi.org/10.1212/WNL.40.2.229

[3] Larsen, J.P., Aarli, J.A., Nyland, H. and Riise, T. (1984) Western Norway, a High-Risk Area for Multiple Sclerosis: A Prevalence/Incidence Study in the County of Hordaland. Neurology, 34, 1202-1207. http://dx.doi.org/10.1212/WNL.34.9.1202

[4] Grønning, M. and Mellgren, S.I. (1985) Multiple Sclerosis in the Two Northern Most Counties of Norway. Acta Psychiatrica et Neurologica Scandinavica, Supplementum, 72, 321-327. http://dx.doi.org/10.1111/j.1600-0404.1985.tb00878.x 
[5] Dick, G. (1976) Theaetiology of Multiple Sclerosis. Proceedings of the Royal Society of Medicine, 69, 611-615.

[6] Lauer, K. and Firnaber, W. (1992) Epidemiologic Aspects of Multiple Sclerosis. Versicherungsmedizin, 44, 125-130.

[7] Swank, R.L. (1950) Multiple Sclerosis, a Correlation of Its Incidence with Dietary Fat. American Journal of the Medical Sciences, 220, 421-430. http://dx.doi.org/10.1097/00000441-195022040-00011

[8] Swank, R.L., Lersted, O., Strøm, A. and Backer, J. (1952) Multiple Sclerosis in Rural Norway. The New England Journal of Medicine, 246, 721-728. http://dx.doi.org/10.1056/NEJM195205082461901

[9] Lauer, K. (1989) Dietary Changes in Temporal Relation to Multiple Sclerosis in the Faroe Islands: An Evaluation of Literary Sources. Neuroepidemiology, 8, 200-206. http://dx.doi.org/10.1159/000110183

[10] Bates D. (1990) Dietary Lipids and Multiple Sclerosis. Upsala Journal of Medical Sciences, 41, 173-187.

[11] Murell, T.G., Harbige, L.S. and Robinson, I.C. (1991) A Review of the Aetiology of Multiple Sclerosis: An Ecological Approach. Annals of Human Biology, 18, 95-112. http://dx.doi.org/10.1080/03014469100001442

[12] Malosse, D., Perron, H., Sasco, A. and Seigneurin, J.M. (1992) Correlation between Milk and Dairy Product Consumption and Multiple Sclerosis Prevalence: A Worldwide Study. Neuroepidemiology, 304-312. http://dx.doi.org/10.1159/000110946

[13] Ben-ashlmomo, Y., Davey-Smith, G. and Marmot, M.G. (1992) Dietary Fat in the Epidemiology of Multiple Sclerosis: Has the Situation Been Adequately Assessed? Neuroepidemiology, 11, 214-215. http://dx.doi.org/10.1159/000110934

[14] Malosse, D. and Perron, H. (1993) Correlation Analysis between Bovine Population, Other than Farm Animals, House Pets, and Multiple Sclerosis Prevalence. Neuroepidemiology, 12, 15-27. http://dx.doi.org/10.1159/000110295

[15] Gorelick, P.B. (1989) Clues to the Mystery of Multiple Sclerosis. Postgraduate Medicine, 85, 125-128, 131-134.

[16] Millar, J.H.D. (1971) Multiple Sclerosis, a Disease Acquired in Childhood. Charles C Thomas, Springfield.

[17] Morris, J.A. (1990) The Age Incidence of Multiple Sclerosis: A Decision Theory Model. Medical Hypotheses, 32, 129-135. http://dx.doi.org/10.1016/0306-9877(90)90036-E

[18] Delasnerie-Laupetre, N. and Alpertovitch, A. (1990) Childhood Infections in Multiple Sclerosis: A Study of North African-Born Patients Who Migrated to France. Neuroepidemiology, 9, 118-123. http://dx.doi.org/10.1159/000110760

[19] Hader, W.J., Irvine, D.G. and Schiefer, H.B. (1990) A Cluster-Focus of Multiple Sclerosis at Henribourd, Saskatchewan. Canadian Journal of Neurological Sciences, 17, 391-394.

[20] Lindberg, C., Andersen, O., Vahlne, A., Dalton, M. and Runmarker, B. (1991) Epidemiological Investigation of the Association between Infectious Mononucleosis and Multiple Sclerosis. Neuroepidemiology, 10, 62-65. http://dx.doi.org/10.1159/000110248

[21] Riise, T. and Klauber, M.R. (1992) Relationship between the Degree of Individual Space-Time Clustering and Age at Onset of Disease among Multiple Sclerosis Patients. International Journal of Epidemiology, 21, 528-532. http://dx.doi.org/10.1093/ije/21.3.528

[22] Dean, G. and Gray, R. (1990) Do Nurses and Doctors Have an Increased Risk of Developing Multiple Sclerosis? Journal of Neurology, Neurosurgery \& Psychiatry, 53, 899-902. http://dx.doi.org/10.1136/jnnp.53.10.899

[23] Waldeyer, W. (1875) Ueber Bindegewebszellen. Arch. Micros. Anat., 11, 176.

[24] Ehrlich, P. (1878) Beiträge zur Theorie und Praxis der histologischen Färbung. Thesis, University of Leipzig, Leipzig.

[25] Galli, S.J. and Lichtenstein, L.M. (1988) Biology of Mast Cells and Basophils. In: Allergy: Principles and Practice, Mosby, St. Louis, 106-134.

[26] Krüger, P.G. and Nyfors, A. (1984) Phagocytosis by Mast Cells in Urticariapigmentosa. Acta Dermato-Venereologica (Stockh), 64, 373-377.

[27] Kambayashi, T., Allenspach, E.J., Chang, J.T., Zou, T., Shoag, J.E., Reiner, S.L., Caton, A.J. and Koretzky, G.A. (2009) Inducible MHC Class II Expression by Mast Cells Supports Effector and Regulatory T-Cell Activation. Journal of Immunology, 182, 4686-4695. http://dx.doi.org/10.4049/jimmunol.0803180

[28] Enerback, L. (1986) Mast Cell Heterogeneity: The Evolution of the Concept of a Specific Mucosal Mast Cell. In: Befus, A.D., et al., Eds., Mast Cell Differentiation and Heterogeneity, Raven Press, New York, 1-26.

[29] Bochner, B.S., Charlesworth, E.N., Lichtenstein, L.M., Derse, C.P., Gillis, S., Dinarello, C.A. and Schleimer, R.P. (1990) Interleukin-1 Is Released at Sites of Human Cutaneous Allergic Reactions. Journal of Allergy and Clinical Immunology, 86, 830-839. http://dx.doi.org/10.1016/S0091-6749(05)80143-5

[30] Krüger, P.G., Aas, P., Onarheim, J. and Helle, K.B. (1982) Neurotensin-Induced Release of Histamine from Rat Mast Cells in Vitro. Acta Physiologica Scandinavica, 114, 467-469. http://dx.doi.org/10.1111/j.1748-1716.1982.tb07011.x

[31] Church, M.K., El-Lati, S. and Caulfield, J.P. (1991) Neuropeptide-Induced Secretion from Human Skin Mast Cells. International Archives of Allergy and Immunology, 94, 310-318. http://dx.doi.org/10.1159/000235393 
[32] Ali, H., Leung, K.B.P., Pearce, F.L., Hayes, N.A. and Foreman, J.C. (1986) Comparison of the Histamine-Releasing Action of Substance P on Mast Cells and Basophils from Different Species and Tissues. International Archives of Allergy and Immunology, 79, 413-418. http://dx.doi.org/10.1159/000234011

[33] Krüger, P.G. and Lagunoff, D. (1981) Mast Cell Restoration. A Study of the Rat Peritoneal Mast Cells after Depletion with Polymyxin B. International Archives of Allergy and Applied Immunology, 65, 278-290.

[34] Dropp, J.J. (1979) Mast Cells in the Human Brain. Acta Anatomica (Basel), 105, 505-513. http://dx.doi.org/10.1159/000145157

[35] Neumann, J. (1890) Über das Vorkommen der sogenannten “Mastzellen” bei pathologishen Veränderung des Gehirns. Archiv für pathologische Anatomie und Physiologie und für klinische Medicin, 122, 378-380. http://dx.doi.org/10.1007/BF01884453

[36] Olsson, Y. (1974) Mast Cells in Plaques of Multiple Sclerosis. Acta Neurologica Scandinavica, 50, 611-618. http://dx.doi.org/10.1111/j.1600-0404.1974.tb02806.x

[37] Thoms, R., Weiner, H.L. and Johnson, D. (1990) Identification of IgE-Positive Cells and Mast Cells in Frozen Sections of Multiple Sclerosis Brains. Journal of Neuroimmunology, 30, 167-177.

[38] Theoharides, T.C. 1990) Mast Cells: The Immune Gate to the Brain. Life Sciences, 46, 607-617. http://dx.doi.org/10.1016/0024-3205(90)90129-F

[39] Krüger, P.G., Bø, L., Myhr, K.M., Karlsen, A.E., Taule, A., Nyland, H.I. and Mørk, S. (1990) Mast Cells and Multiple Sclerosis: A Light and Electron Microscopic Study of Mast Cells in Multiple Sclerosis Emphasizing Staining Procedures. Acta Neurologica Scandinavica, 81, 31-36. http://dx.doi.org/10.1111/j.1600-0404.1990.tb00927.x

[40] Ibrahim, M.Z.M., Reder, A.T., Lawand, R., Takash, W. and Sallouh-Khatib, S. (1996) The Mast Cells of the Multiple Sclerosis Brain. Journal of Neuroimmunology, 70, 131-138. http://dx.doi.org/10.1016/S0165-5728(96)00102-6

[41] Krüger, P.G. (2001) Mast Cells and Multiple Sclerosis: A Quantitative Analysis. Neuropathology and Applied Neurobiology, 27, 275-280. http://dx.doi.org/10.1046/j.0305-1846.2001.00331.X

[42] Krüger, P.G. and Mørk, S. (2012) Mast Cells and Multiple Sclerosis in Females and Males. World Journal of Neuroscience, 2, 145-149. http://dx.doi.org/10.4236/wjns.2012.23022

[43] Orton, S.M., Herrera, B.M., Yee, I.M., Valdar, W., Ramagopalan, S.V., Sadovnick, A.D. and Ebers, G.C. (2006) Sex Ratio of Multiple Sclerosis in Canada, a Longitudinal Study. Lancet Neurology, 5, 932-936. http://dx.doi.org/10.1016/S1474-4422(06)70581-6

[44] Rozniecki, J.J., Hauser, S.L., Stein, M., Lincoln, R. and Theoharides, T.C. (1995) Elevated Mast Cell Tryptase in Cerebrospinal Fluid of Multiple Sclerosis Patients. Annals of Neurology, 37, 63-66. http://dx.doi.org/10.1002/ana.410370112

[45] Johnson, D., Seeldrayers, P.A. and Weiner, H.L. (1988) The Role of Mast Cells in Demyelination. I Myelin Proteins Are Degraded by Mast Cell Proteases and Myelin Basic Protein and $\mathrm{P}_{2}$ Can Stimulate Mast Cell Degranulation. Brain Research, 444, 195-198. http://dx.doi.org/10.1016/0006-8993(88)90929-8

[46] Grytten, N., Glad, S.B., Aarseth, J.H., Nyland, H., Midgard, R. and Myhr, K.M. (2006) A 50-Year Follow-Up of the Incidence of Multiple Sclerosis in Hordaland County, Norway. Neurology, 66, 182-186. http://dx.doi.org/10.1212/01.wnl.0000195549.95448.b9

[47] Gross, M. (2010) Piercing Together the Causes of Lives Torn Apart. Oxford Today, 22, 20-21.

[48] Jasani, B., Kreil, G., Mackler, B.F. and Stanworth, D.R. (1979) Further Studies on the Structural Requirements for Polypeptide-Mediated Histamine Release from Rat Mast Cells. Biochemical Journal, 181, 623-632.

[49] Krüger, P.G., Mahata, S.K. and Helle, K.B. (2003) Catestatin $\left(\mathrm{CgA}_{344-364}\right)$ Stimulates Rat Mast Cell Release of Histamine in a Manner Comparable to Mastoparan and Other Cationic Charged Neuropeptides. Regulatory Peptides, 114, 29-35. http://dx.doi.org/10.1016/S0167-0115(03)00069-7

[50] Wilson, L.M. and Baldwin, A.L. (1999) Environmental Stress Causes Mast Cell Degranulation, Endothelial Changes, and Edema in the Rat Intestinal Mucosa. Microcirculation, 6, 189-198. http://dx.doi.org/10.1080/725310748

[51] Hauser, R. and Calafat, A.M. (2005) Phthalates and Human Health. Occupational and Environmental Medicine, 62, 806818. http://dx.doi.org/10.1136/oem.2004.017590

[52] Nakamura, R., Teshima, R. and Sawada, J.I. (2002) Effect of Dialkyl Phthalates on the Degranulation and Ca ${ }^{2+}$ Response of RBL-2H3 Mast Cells. Immunology Letters, 80, 119-124. http://dx.doi.org/10.1016/S0165-2478(01)00318-2 